\title{
ДІЯЛЬНІСТЬ КОЛЕКТОРСЬКИХ КОМПАНІЙ НА РИНКУ ФІНАНСОВИХ ПОСЛУГ: ПРАВОВІ АСПЕКТИ
}

\author{
ТРОЦЮК Ніна Валерї̈вна - кандидат юридичних наук, Юридичний \\ факультет, Національний авіаційний університет \\ https://orcid.org/0000-0002-5943-8694 \\ УДК $346.62(045)$ \\ DOI 10.32782/NP.2021.2.22
}

Цель статьи заключается в определенньии этапов возникновения рьина коллекторских услуг в Украине и раскрьттии особенностей правового регулирования деятельности коллекторских компаний на рылнке фбинансовъгх услуг в связи с принятием Закона Украинъ №1349$I X$ «О внесении изменений в некоторье законодательные акть Украинъ относительно защить должников при урегулировании просроченной задолженности». Для достижения поставленной цеели бълли использованъ методъи, в частности такие? как: диалектический, формально-юридический, системно-структурньии, логико-семантический, компаративнъий, а также метод анализа действующего отечественного законодательства. Обсуждения. Подчеркнуто, что учитьивая опьт европейских стран о деятельности коллекторских компаний на рьинке бинансовъхх услуг, Украина впервъие определила требования по взаимодействию с потребителями и другими лицами при урегулировании просроченной задолженности (требования к этическому поведению) и ответственность за нарушение требований к этическому поведению.

Ключевъе слова: потребительское кредитование, микроббнансовая организачия, кредитор, новъий кредитор, заемшик, коллекторская компания, реестр коллекторских компаний.

Постановка проблеми та їі актуальність

Нестабільна фінансова ситуація, економічна криза та зростання безробіття в Україні спровокували збільшення рівня непогашеної заборгованості населення на ринку кредитування та обумовили появу нового виду послуг (колекторських послуг), спрямованих на погашення у позасудовому порядку заборгованості споживача, який прострочив виконання грошового зобов'язання за договором про споживчий кредит, укладеним із комерційними банками та небанківськими фінансовими установами - мікрофінансовими організаціями.

Діяльність колекторських компаній в Україні більше десяти років не мала належного правового регулювання, а термін «колекторська компанія» в законодавстві взагалі був відсутній. Основним документом, де згадувалося про легальність колекторської діяльності, був Аист Державної служби України 3 питань регуляторної політики та розвитку підприємництва № 7747 від 27 серпня 2013 р., у якому зазначалося, що колекторська компанія може діяти від імені кредитора на підставі договору доручення або надання послуг за певну винагороду [1]. Такі компанії 3 надання колекторських послуг були зареєстровані як компанії з надання факторингових послуг.

На сьогодні в Україні діє більше 200-т колекторських компаній, які не завжди дотримуються вимог щодо етичної поведінки. Свідченням цього є 1043 письмові звернення стосовно колекторської діяльності («collection діяльності») банків та небанківських фінансових установ, які надійшли протягом третього кварталу 2020 року до Національного банку України. 3 них 77 звернень надійшло стосовно банків та 966 - небанківських фінансових 


\section{Цивільне, підприсмницьке, господарське та трудове право}

установ [2]. У $70 \%$ звернень стосовно collection діяльності банків споживачі скаржились на достатньо грубі форми роботи банків відносно своїх клієнтів, та у майже половині звернень $з$ приводу collection діяльності фінансових компаній були наявні випадки дуже жорстоких форм поводження з боржниками для примусового повернення заборгованостей.

Враховуючи цю статистику, держава вирішила забезпечити захист прав боржників та третіх осіб під час врегулювання простроченої заборгованості шляхом запровадження на законодавчому рівні вимог до етичної поведінки кредитодавців та колекторських компаній під час взаємодії із споживачами. Так, 19 березня 2021 року Парламентом прийнято Закон України «Про внесення змін до деяких законодавчих актів України щодо захисту боржників при врегулюванні простроченої заборгованості» [3], яким вперше визначено поняття «колекторська компанія» та визначено вимоги щодо етичної поведінки цих компаній.

Усе вище викладене свідчить про актуальність дослідження правових аспектів діяльності колекторських компаній на ринку фінансових послуг в Україні.

\section{Стан дослідження}

Питання, пов’язані 3 діяльністю колекторських компаній в Україні піднімали у своїх працях такі науковці та юристи-практики, як: А. М. Авторгов, О. В. Двірська, О. Б. Денис, С. В. Дяченко, А. О. Іванов, К. А. Ааріонова, В. П. Мочернюк, Р. В. Мітітел, Т. В. Романцова, I. М. Суслова, Т. В. Філіпенко, В. В. Філатов, К. І. Фоміна, В. С. Яременко та інші. Проте, їх дослідження стосувалися здебільшого висвітленню етапів розвитку колекторського бізнесу, аналізу судової практики розгляду спорів із колекторами, міжнародної практики функціонування колекторських компаній, особливостей створення таких структур на українському ринку фінансових послуг.

Віддаючи належне напрацюванням дослідників, варто зазначити, що правові аспекти діяльності колекторських компаній в Україні розглядались здебільшого у загальному контексті кредитних відносин та без урахування останніх змін до законодавства щодо захисту споживачів при врегулюванні простроченої заборгованості.

Мета статті полягає у дослідженні правових аспектів діяльності колекторських компаній в Україні у зв'язку із прийняттям Закону України від 19.03.2021 р. № №1349-IX «Про внесення змін до деяких законодавчих актів України щодо захисту боржників при врегулюванні простроченої заборгованості».

\section{Виклад основних положень}

В Україні 2008 рік вважається роком виникнення ринку колекторських послуг, адже з підвищенням курсу американського долара 3 п’яти до восьми гривень, число порушень договірних зобов'язань за валютними кредитами різко зросло. Банки були готові до реструктуризації заборгованості позичальників. Aле, не зважаючи на значні часові та грошові витрати, для вирішення питання щодо повернення боргів, фінансові установи були змушені звернутися за допомогою до колекторських компаній.

Другим етапом розвитку ринку колекторських послуг можна назвати 2014 рік, адже саме тоді багато українських банків були позбавлені ліцензій, та, як наслідок, з'явилась велика кількість кредитних портфелів. Саме це призвело до появи декількох типів колекторських компаній:

$\checkmark$ Колл-цуентри - діяльність яких зосереджена на здійсненні дзвінків боржникам та на повернення боргів 3 мінімальними витратами.

$\checkmark$ «Професійні колектори» - компанії, які не обмежувалися дистанційною формою спілкування та застосовували погрози й насильство, через що стали «популярними» представниками ринку цих послуг.

$\checkmark$ Факторингові компанї, мета яких робота 3 найбільш якісними кредитами, які забезпечені ліквідною нерухомістю [4].

Основними видами послуг, які пропонували на той час вітчизняні колекторські компанії, на думку аналітиків, були: [5, с. 67-68]

1. Викуп заборгованості клієнта.

2. Сім видів послуг досудового стягнення заборгованості: 1) досудова робота 3 рухомим майном, яка включає у себе конфіскацію майна у боржника $з$ доставкою на майданчик 
кредитора, оформлення документів щодо заставного майна тощо; 2) юридичний супровід боргу (сукупність дій зі стягнення заборгованості в судовому порядку, а також через третейські суди); 3) комплексний супровід виконавчого виробництва (пошук майна боржника, опис і відповідальне зберігання майна); 4) моніторинг предметів застави (оцінка та інформування заставних підрозділів кредиторів про наявність та стан прийнятого ними в заставу або переданого в лізинг майна);5) кредитний моніторинг (контроль та моніторинг виконання позичальниками платіжних зобов'язань, дотримання ними термінів оплати і графіків платежів); 6) ранній колекшн (стягнення заборгованості на ранній стадії існування боргу за допомогою дистанційного контакту з боржником, регулярних повідомлень і нагадувань (пошта, SMS, e-mail, дзвінки)); 7) пізній колекшн (стягнення на пізній стадії існування боргу. Повна процедура стягнення заборгованості за допомогою більш інтенсивних методів дистанційного впливу й особистих контактів із боржником) $[6 ; 7]$.

Зауважимо, що загалом робота вітчизняних колекторських компаній на той час суперечила основним принципам колекторної діяльності - тактовно і ненав'язливо нагадувати про наявний кредит та відповідальність за отриману в борг суму грошей, а основна проблема полягала у відсутності належного правового регулювання діяльності цих компаній. Адже на законодавчому рівні не було визначено правовий статус колекторських компаній, не врегульовано їх діяльність та компетенцію [8, с. 130]

Суб'єктами законодавчої ініціативи неодноразово робились спроби врегулювати діяльність цих компаній в Україні. Так, законопроєктом №2275 від 02.03.2015 «Про заборону надання колекторських послуг щодо фізичних осіб - боржників» пропонувалося заборонити надання колекторських послуг щодо виконання фінансових зобов'язань, однак він був відхилений через невідповідність нормам європейського законодавства. У 2019 році вдруге були зроблені спроби захистити права та законні інтереси боржників при здійсненні колекторської діяльності, шляхом прийняття законопроєкту №2133 від
12.09.2019 «Про захист прав та законних інтересів боржників при здійсненні колекторської діяльності». Однак вказаний законопроєкт пройшов тільки етап першого читання i не був прийнятий [4]. Аише третя спроба дала позитивний результат і законопроєкт №4241 від 21.10.2020 «Про внесення змін до деяких законодавчих актів України щодо захисту боржників при врегулюванні простроченої заборгованості» (далі - Закон) 19 березня 2021 року був прийнятий Верховною Радою України.

Хоча зазначений Закон набув чинності 14 квітня 2021 року, проте деякі науковці, юристи-практики, народні депутати не підтримують думку щодо нагальності його прийняття та вказують на певні прогалини.

Так, наприклад, народний депутат України 8-го скликання, Голова жіночого руху «За майбутне» I. М. Суслова у своїх дописах в соціальних мережах зазначає, що на повну силу цей законодавчий акт запрацює мінімум через три місяці, коли Національний банк України створить реєстр, так би мовити, офіційних колекторських компаній. I хоча цим Законом передбачено низку обмежень для колекторів у межах взаємодії з боржниками, повністю проблему він не розв'язує. Питання про нарахування безпідставно високих відсотків за кредитом, встановлення кредитором неможливих умов повернення заборгованості, незрозумілі штрафи та юридичні «уловки», що, по суті, вводять позичальника в оману, залишаються не вирішеними цим законодавчим актом. На її думку, в умовах війни, економічної кризи та пандемії COVID-19 дозволяти роботу сумнівних фінансових установ, які заробляють на бідності та вразливості громадян - такий самий злочин, як і вибивання боргів усіма можливими методами. Держава насамперед повинна забезпечити прозору банківську систему, захищеність позичальників, цивілізовані методи роботи з боржниками [9].

На думку А. О. Іванова, Закон містить низку положень, що мають оціночний i суб'єктивний характер (використовуються терміни «невідкладно», «адекватно»), та створює нові поняття без визначення їх значення (наприклад, «заходи, спрямовані на погашення у позасудовому порядку заборгованості 


\section{Цивільне, підприсмницьке, господарське та трудове право}

споживача»). Двозначність і нечіткість норм неодмінно створить підстави для конфлікту у відносинах, а також є такою, що не відповідає принципам правової визначеності.

Старший юрист AO «MORIS GROUP» зазначає, що після початку дії Закону частина колекторських компаній буде працювати на ринку нелегально, без відповідних дозволів НБУ, що призведе до розвитку ринку «індивідуальних колекторів», які здійснюватимуть таку діяльність без укладення договорів 3 кредиторами та за межами правового поля. Тому важливою в цій ситуації буде реакція правоохоронних органів на таких осіб, адже колекторська діяльність поза межами контролю НБУ автоматично підпадає під ознаки такого злочину, як вимагання та ведення бізнесу без відповідних дозволів [10].

А. М. Авторгов вважає, що ухвалений Закон направлений не на захист прав споживачів, а на легалізацію в Україні колекторської діяльності, оскільки він легалізує певну частину колекторських компаній, які виявлять бажання працювати «вбілу», проте жодним чином не стає на заваді «чорним колекторам», які як здійснювали свою незаконну діяльність, так і будуть їі здійснювати. На його думку, потрібно розвивати легальну юстицію, а не легалізовувати тіньову. Адже держава вкрай незадовільно фінансує суди та Державну виконавчу службу, не сприяє розвитку інституту приватних виконавців, натомість узаконила діяльність так званих колекторських компаній, створивши їм широке поле для діяльності, яка не має нічого спільного ані з цивілізованим та правовим вирішенням фінансових спорів, ані з верховенством права [11].

Аналізуючи текст Закону України «Про внесення змін до деяких законодавчих актів України щодо захисту боржників при врегулюванні простроченої заборгованості» [3], відзначимо, що ним вперше передбачаються терміни «врегулювання простроченої заборгованості», «реєстр колекторських компаній», «колекторська компанія», «новий кредитор».

Згідно 3 п. $4^{1}$ ч.1. ст.1 Закону України «Про споживче кредитування», колекторська компанія - юридична особа (у тому числі небанківська фінансова установа, яка відповідно до закону має право надавати кошти у позику, у тому числі на умовах фінансового креди- ту, та/або послуги з факторингу), включена до реєстру колекторських компаній, яка в інтересах кредитодавця (первісного кредитора) та/ або нового кредитора (у разі заміни первісного кредитора) відповідно до договору з таким кредитодавцем та/або новим кредитором має право здійснювати врегулювання простроченої заборгованості [12].

Цим законодавчим актом також доповнено Закон України «Про споживче кредитування» окремим III Розділом «Врегулювання простроченої заборгованості», який включає вимоги щодо взаємодії із споживачами та іншими особами при врегулюванні простроченої заборгованості (наприклад, проведення особистих зустрічей можливе тільки з до 19 години, надсилання текстових, голосових та інших повідомлень через засоби телекомунікації, надсилання поштових відправлень із позначкою «Вручити особисто») (див. Таблиця 1). Закріплено також права та обов'язки суб'єктів договору про надання споживчого кредиту при врегулюванні простроченої заборгованості. Наприклад, забороняється телефонувати боржнику з 20:00 до 9:00, а також у вихідні та свята, використовувати функцію автоматичного дозвону більше 30 хвилин на добу, взаємодіяти із споживачем, його близькими більше двох разів на добу, приховувати інформацію про номер контактного телефону, з якого здійснюється дзвінок або надсилається повідомлення споживачу та іншу контактну інформацію, особи, яка взаємодіє 3 боржником або його представником тощо (ст. 25 Закону України «Про споживче кредитування»).

Залучення ж колекторської компанії до процесу повернення боргу можливе лише за умови, що таке право прямо передбачено кредитним договором. При цьому, протягом 10 робочих днів банк повинен повідомити клієнта про свої наміри.

Державне регулювання та нагляд за дотриманням колекторськими компаніями законодавства про захист прав споживачів покладено Законом на Національний банк України (ст. ст. 26, 27 Закону України «Про споживче кредитування»).

Передбачено також правові підстави набуття статусу колекторської компанії. Так, відповідно до ст. 22 Закону України «Про 
споживче кредитування» [12], юридична особа, яка має намір набути статус колекторської компанії (крім небанківської фінансової установи), подає до Національного банку України відповідно до вимог, у порядку та за формою, що встановлені нормативно-правовими актами Національного банку України, такі
3 питань встановлених законодавством вимог щодо взаємодії із споживачами при врегулюванні простроченої заборгованості (вимог щодо етичної поведінки), захисту прав споживачів та обробки персональних даних; 8) документ, що підтверджує внесення заявником встановленої Національним банком

Таблиця 1

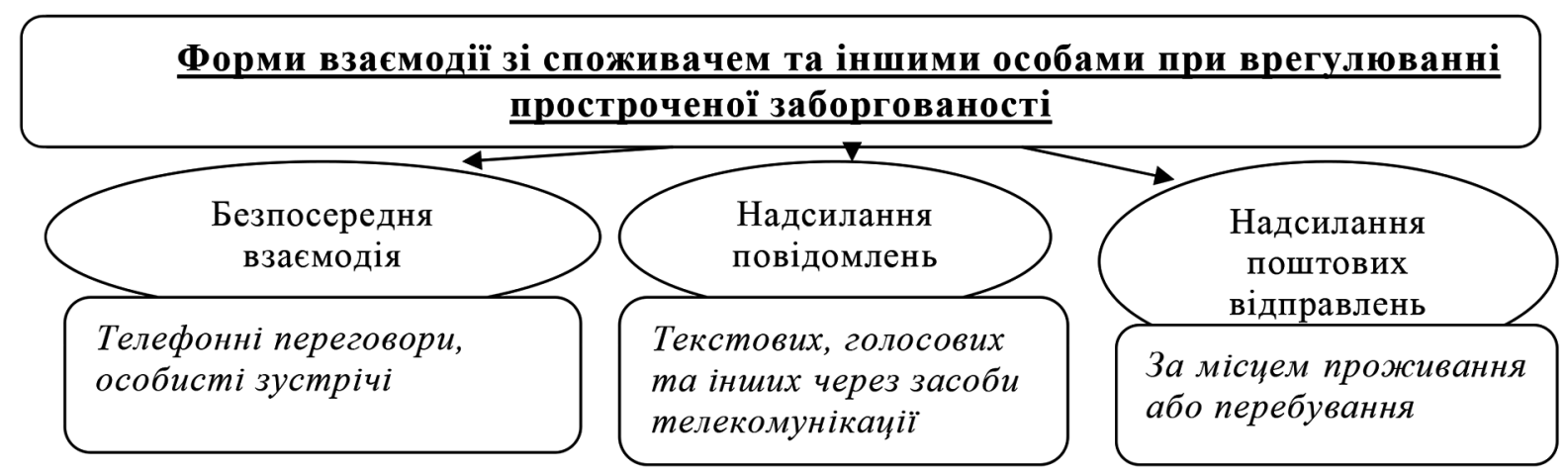

документи:

1) заява про включення до реєстру колекторських компаній; 2) анкета заявника 3 описом його бізнес-намірів; 3) документи, що містять відомості про керівників, працівників заявника, осіб, залучених заявником на підставі цивільно-правових договорів для безпосередньої взаємодії із споживачами, разом із письмовим запевненням про їх відповідність кваліфікаційним вимогам, встановленим цим Законом та нормативно-правовими актами Національного банку України; 4) документи, що містять відомості про власників істотної участі заявника, та документи, визначені нормативно-правовими актами Національного банку України, що підтверджують відповідність власників істотної участі заявника вимогам, встановленим цим Законом та нормативно-правовими актами Національного банку України; 5) документи, що містять відомості про структуру власності заявника;6) анкета заявника щодо політик та внутрішніх положень заявника щодо взаємодії із споживачами, захисту персональних даних, порядку організації та проведення навчання і підвищення кваліфікації працівників; 7) письмове запевнення керівників про проходження працівниками заявника, третіми особами, залученими заявником на підставі цивільно-правових договорів для безпосередньої взаємодії із споживачами, навчання
України плати за розгляд пакета документів.

За результатами розгляду документів заявника Національний банк України приймає рішення про включення заявника до реєстру колекторських компаній або про відмову у включенні протягом 30 робочих днів 3 дня подання повного пакета документів.

Заявник набуває статусу колекторської компанії та право здійснювати врегулювання простроченої заборгованості з дня включення відомостей про нього до реєстру колекторських компаній.

Відзначимо, що Законом вперше закріплено відповідальність за порушення під час врегулювання простроченої заборгованості (вимоги щодо етичної поведінки). Так, згідно ч. 1 ст. 28 Закону України «Про споживче кредитування» [12], у разі порушення законодавства про захист прав споживачів фінансових послуг, у тому числі вимог щодо взаємодії із споживачами при врегулюванні простроченої заборгованості (вимог щодо етичної поведінки), Національний банк України має право у встановленому ним порядку застосувати такі заходи впливу, адекватні вчиненому порушенню (див. Таблиця 2):

1) направити кредитодавцю, новому кредитору та/або колекторській компанії письмове застереження 3 вимогою про усунення виявленого порушення та/або вжиття заходів 
для недопущення такого порушення у подальшій діяльності (далі - письмове застереження);

2) накласти відповідно до Закону України «Про фінансові послуги та державне регулювання ринків фінансових послуг» штраф на кредитодавця, нового кредитора та/або колекторську компанію у розмірі від 3000 до 6000 неоподатковуваних мінімумів доходів громадян [13];

3) тимчасово заборонити колекторській компанії здійснювати врегулювання простроченої заборгованості;

4) виключити відомості про колекторську компанію з реєстру колекторських компаній;

5) тимчасово зупинити або відкликати (анулювати) ліцензію кредитодавця - небанківської фінансової установи, нового кредитора - небанківської фінансової установи на провадження діяльності з надання фінансових послуг.

\section{Висновок}

Підсумовуючи вище викладене, зазначимо, що належне правове регулювання діяльності колекторських компаній в Україні відіграватиме важливу роль в умовах економічної кризи та зростання непогашеної заборгованості населення на ринку кредитування. Враховуючи досвід європейських країн щодо діяльності колекторських компаній на ринку фінансових послуг, Україна прийнявши Закон України «Про внесення змін до деяких законодавчих актів України щодо захисту боржників при врегулюванні простроченої заборгованості» наблизилася до стандартів Европейського Союзу та Сполучених Штатів Америки 3 питань врегулювання простроченої заборгованості. Адже вперше цим законодавчим актом визначено поняття «колекторська компанія», встановлено вимоги щодо взаємодії із споживачами та іншими особами при врегулюванні простроченої заборгованості та відповідальність за порушення вимог щодо етичної поведінки. Саме встановлені вимоги щодо етичної поведінки, на нашу думку, покликані певним чином захистити права споживачів-боржників та обмежити доступ до ринку потенційно недобросовісних колекторів.

Проте, незважаючи на позитивні аспекти прийняття цього Закону, слід зауважити, що він врегульовує колекторську діяльність лише в частині споживчого кредитування. При такому підході без правового захисту залишаються інші категорії осіб, які уклали кредитні або інші договори, за якими виникла грошова заборгованість. Це фізичні особи-підприємці, юридичні особи, зокрема, малий бізнес, які теж страждають від свавілля колекторів та недобросовісних дій кредито-

Таблиця 2

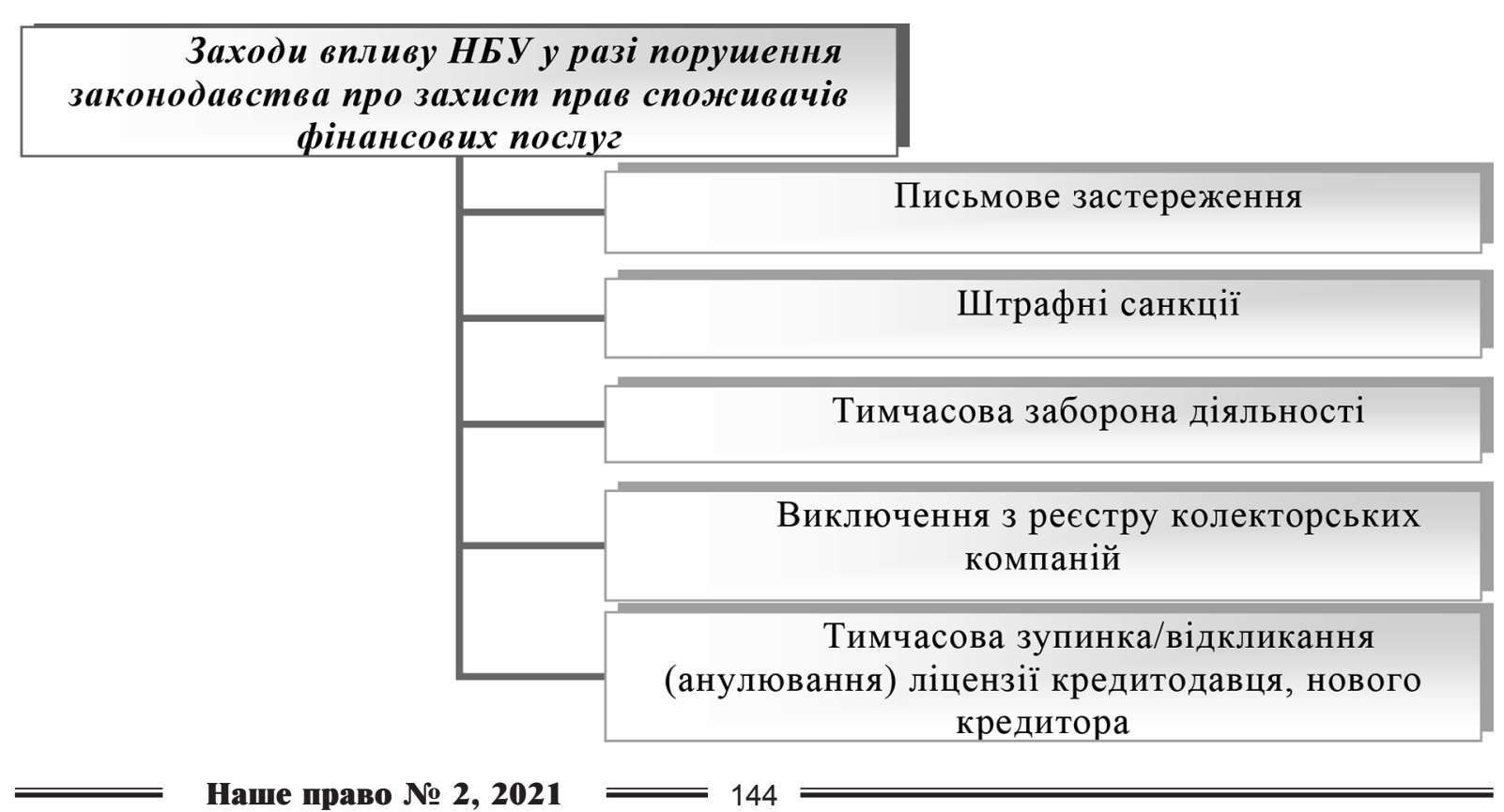


рів. Також у цьому законодавчому акті відсутні механізми, що регулюють продаж боргів і способи реструктуризації, не закріплено кримінальну відповідальність колекторів за порушення під час врегулювання простроченої заборгованості. Вважаємо, що ці питання потребують врегулювання у спеціальному законодавчому акті про колекторську діяльність.

\section{Література}

1. Аист Державної служби України з питань регуляторної політики та розвитку підприємництва від 27.08.2013 р. № 7747/0/2013. URL: https://zakon.rada.gov.ua/rada/show/ v7747773-13\#Text

2. Захист прав споживачів фінансових послуг: робота зі зверненнями у 3 кварталі 2020 року. URL: https://ba nk.gov.ua/admin_uploads/ article/ZG 2020-Q3.pdf

3. Про внесення змін до деяких законодавчих актів України щодо захисту боржників при врегулюванні простроченої заборгованості : Закон України від 19.03.2021 р. № №1349-IX. URL: https://zakon.rada.gov.ua/ laws/show/1349-IX\#Text.

4. Романцова Т. Здобутки нового закону про колекторів. URL: https://zib.com. ua/ua/147337-zdobutki_novogo_zakonu_pro_ kolektoriv.html

5. Денис О. Б. Проблеми та перспективи розвитку колекторського бізнесу в Україні. Науковий вісник Міжнародного гуманітарного університету. Серія : Економіка $і$ менеджмент. 2018. Вип. 34. С. 66-70.

6. Захист персональних даних і колектори. Актуальні проблеми і практика їх вирішення / Протокол. URL: protokol.com. ua/ua/ zahist_personalnih_danih_i_kolektori_ aktualni_problemi_i_praktika_ih_virishennya.

7. Колекторський ринок України в 2014 році: актуальний зріз стану галузі / Банкхарт. URL: http://www.bankchart.com.ua/biznes/ rozvitok_biznesu/statti/kolektorskiy_rinok_ ukrayini_v_2014_rotsi_aktualniy_zriz_stanu_ galuzi.

8. Дяченко С.В., Яременко В.С. Судова практика розгляду спорів із коллекторами. Юридичний науковий електронний журнал. 2020. №3. C.130-133.
9. Суслова Ірина. Чи ослабне колекторський терор? URL: https://rus.lb.ua/blog/iryna_ suslova/482424_chi_oslabne_kolektorskiy_teror. html.

10. Іванов А. Закон про захист боржників від недобросовісних колекторів: якісні зміни чи профанація? URL: https:/uba.ua/ukr/ news/8378/.

11. Авторгов А. Про безпорадність антиколекторського закону. URL: https:// borgexpert.com/stiahnennia-borhiv/kolektory/ pro-bezporadnist-antykolektorskoho-zakonu.

12. Про споживче кредитування : Закон України від 15.11.2016 р.№ 1734-VIII. Відомості Верховної Ради Украӥни. 2020. № 39. CT. 294.

13. Про фінансові послуги та державне регулювання ринків фінансових послуг : Закон України від 12.07.2001 р. № 2664-III. Відомості Верховної Ради Украӥни. 2021. № 4. Ст. 26.

\section{References}

1. Lyst Derzhavnoi sluzhby Ukrainy $\mathrm{Z}$ pytan rehuliatornoi polityky ta rozvytku pidpryiemnytstva vid 27.08.2013 r. № 7747/0/2013. URL: https://zakon.rada.gov.ua/rada/show/ v7747773-13\#Text

2. Zakhyst prav spozhyvachiv finansovykh posluh: robota zi zvernenniamy u 3 kvartali 2020 roku. URL: https://ba nk.gov.ua/admin_uploads/ article/ZG_2020-Q3.pdf

3. Pro vnesennia zmin do deiakykh zakonodavchykh aktiv Ukrainy shchodo zakhystu borzhnykiv pry vrehuliuvanni prostrochenoi zaborhovanosti : Zakon Ukrainy vid 19.03.2021 r. № №1349-IKh. URL: https://zakon.rada.gov. ua/laws/show/1349-IX\#Text.

4. Zdobutky novoho zakonu pro kolektoriv. URL: https://zib.com.ua/ua/147337-zdobutki_ novogo_zakonu_pro_kolektoriv.html

5. Denys O. B. Problemy ta perspektyvy rozvytku kolektorskoho biznesu v Ukraini. Naukovyi visnyk Mizhnarodnoho humanitarnoho universytetu. Seriia : Ekonomika i menedzhment. 2018. Vyp. 34. S. 66-70.

6. Zakhyst personalnykh danykh i kolektory. Aktualni problemy i praktyka yikh vyrishennia / Protokol. URL: protokol.com.ua/ua/ zahist_personalnih_danih_i_kolektori_aktualni_ problemi_i_praktika_ih_virishennya. 


\section{Цивільне, підприсмницьке, господарське та трудове право}

\section{АНОТАЦІЯ}

Мета статті полягає у визначені етапів виникнення ринку колекторсъких послуг в Україні та розкритті особливостей правового регулювання діяльності колекторсъких компаній на ринку бонансових послуг у зв'язку iз прийняттям Закону Украӥни №1349-IX «Про внесення змін до деяких законодавчих актів України щодо захисту боржників при врегулюванні простроченої заборгованості». Для досягнення визначеної мети були використані методи, зокрема такі як: діалектичний, бормально-юридичний, системноструктурний, логіко-семантичний, компаративний, а також метод аналізу чинного вітчизняного законодавства. Обговорення. Підкреслено, що враховуючи досвід європейсъких краӥн щодо діяльності колекторсъких компаній на ринку фінансових послуг, Украйна вперше визначила вимоги щодо взаємодї із споживачами та іншими особами при врегулюванні простроченої заборгованості (вимоги щодо етичної поведінки) та відповідальність за порушення вимог щодо етичної поведінки.

Ключові слова: споживче кредитування, мікроббінансова організачія, кредитор, новий кредитор, позичальник, колекторсъка компанія, реєстр колекторсъких компаній.

7. Kolektorskyi rynok Ukrainy v 2014 rotsi: aktualnyi zriz stanu haluzi / Bankkhart. URL: http://www.bankchart.com.ua/biznes/ rozvitok_biznesu/statti/kolektorskiy_rinok_ ukrayini_v_2014_rotsi_aktualniy_zriz_stanu_galuzi.

8. Diachenko S.V., Yaremenko V.S. Sudova praktyka rozghliadu sporiv iz kollektoramy. Yurydychnyi naukovyi elektronnyi zhurnal. 2020. №3. S.130-133.

9. Suslova Iryna. Chy oslabne kolektorskyi teror? URL: https://rus.lb.ua/blog/iryna_suslova/482424_chi_oslabne_kolektorskiy_teror.html.

10. Ivanov A. Zakon pro zakhyst borzhnykiv vid nedobrosovisnykh kolektoriv: yakisni zminy chy profanatsiia? URL: https:/uba.ua/ukr/ news/8378/.

11. Avtorhov A. Pro bezporadnist antykolektorskoho zakonu. URL: https:// borgexpert.com/stiahnennia-borhiv/kolektory/ pro-bezporadnist-antykolektorskoho-zakonu.

12. Pro spozhyvche kredytuvannia : Zakon Ukrainy vid 15.11.2016 r.№ 1734-VIII. Vidomosti Verkhounoi Rady Ukrainy. 2020. № 39. St. 294.

13. Pro finansovi posluhy ta derzhavne rehuliuvannia rynkiv finansovykh posluh : Zakon Ukrainy vid 12.07.2001 r. № 2664-III. Vidomosti Verkhownoi Rady Ukrainy. 2021. № 4. St. 26.

\section{TROTSIUK Nina - Candidate of Law, Faculty of Law, \\ National Aviation University ACTIVITIES OF COLLECTION COMPANIES IN THE FINANCIAL SERVICES MARKET: LEGAL ASPECTS}

Despite numerous studies related to the activities of collection companies, it should be noted that the legal aspects of their activities were considered mostly in the general context of credit relations and without taking into account recent changes in consumer protection legislation in settling overdue debts.

In the article the author identifies the stages of the market of collection services in Ukraine and reveals the features of legal regulation of collection companies in the financial services market in connection with the adoption of the Law of Ukraine №1349-IX “ On amendments to some legislative acts of Ukraine to protect debtors overdue debt".

It was emphasized that taking into account the experience of European countries in the activities of collection companies in the financial services market, Ukraine for the first time defined requirements for interaction with consumers and others in settling overdue debts (ethical conduct requirements) and liability for violating ethical conduct.

It is established that the norms of the current legislation on the protection of the rights of debtors and third parties during the settlement of overdue debts regulate collection activities only in the part of consumer lending. It is stated that in this legislative act there are no mechanisms regulating the sale of debts and methods of restructuring, there is no criminal liability of collectors for violations during the settlement of overdue debts.

It is concluded that it is necessary to resolve the above issues in a special legislative act on collection activities.

Key words: consumer crediting, credit, consumer credit, consumer credit agreement, lender, consumer. 